\title{
Biology and Management of Pusley (Richardia L.) in Tomato, Pepper, Cucurbit, and Strawberry Production ${ }^{1}$
}

\author{
Shaun M. Sharpe, Nathan S. Boyd, Chris Marble, and Shawn Steed ${ }^{2}$
}

\section{Introduction}

Pusley (Richardia L.) species are widespread and common weeds in Florida vegetable and strawberry production. Four species of pusley (Richardia) occur in Florida (Lewis and Oliver 1974). We refer to the native plant Richardia scabra L. as Florida pusley. This discrimination is necessary because these species are often mislabeled and referred to collectively as Florida pusley due to overlapping distributions, similar growth habits and leaf morphologies, and difficulty in identification without the presence of fruit.

The three South American Richardia species with distributions in Florida are Brazil pusley (tropical Mexican clover) (R. brasiliensis Gomes), largeflower pusley (largeflower Mexican clover) (R. grandiflora [Cham. \& Schltdl.] Schult. \& Schult. f.), and South American Mexican clover ( $R$. humistrata [Cham. \& Schltdl.] Schult. \& Schult. f.) (Lewis and Oliver 1974). Of these four, Florida pusley and Brazil pusley are of the most concern. Brazil pusley has been identified as the only Richardia species occupying Florida citrus groves in 14 counties (Chandran and Singh 2003). Florida pusley has been identified as a problem weed in cucurbits and fruiting vegetables in Florida (Webster 2014). South American Mexican clover is a perennial (Lewis and Oliver 1974) and may be less common in cultivated fields.

\section{Species Description}

Class: Dicotyledonous plants

Family: Rubiaceae (coffee or madder family)

\section{Other Common Names:}

Florida pusley: rough Mexican clover, Florida snow weed

Brazil pusley: tropical Mexican clover

Largeflower pusley: largeflower Mexican clover

Life Span: Florida, Brazil, and largeflower pusley are annuals, though Brazil pusley and largeflower pusley may become perennial at the field borders where tillage is minimal.

Habitat: Florida pusley, Brazil pusley, and largeflower pusley generally share similar habitats including cultivated areas, fields, flowerbeds, lawns and turf, pastures, and waste sites (Bryson and DeFelice 2009, Lewis and Oliver 1974).

1. This document is HS1331, one of a series of the Horticultural Sciences Department, UF/IFAS Extension. Original publication date June 2019. Visit the EDIS website at https://edis.ifas.ufl.edu for the currently supported version of this publication.

2. Shaun M. Sharpe, postdoctoral associate; Nathan S. Boyd, associate professor, Horticultural Sciences Department, UF/IFAS Gulf Coast Research and Education Center; Chris Marble, assistant professor, Environmental Horticulture Department, UF/IFAS Mid-Florida Research and Education Center; and Shawn Steed, Extension agent II, Environmental Horticulture Department, UF/IFAS Extension Hillsborough County; UF/IFAS Extension, Gainesville, FL 32611.

The use of trade names in this publication is solely for the purpose of providing specific information. UF/IFAS does not guarantee or warranty the products named, and references to them in this publication do not signify our approval to the exclusion of other products of suitable composition. Use pesticides safely. Read and follow directions on the manufacturer's label. All chemicals should be used in accordance with directions on the manufacturer's label.

The Institute of Food and Agricultural Sciences (IFAS) is an Equal Opportunity Institution authorized to provide research, educational information and other services

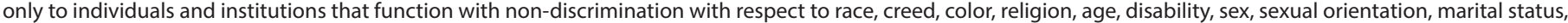
national origin, political opinions or affiliations. For more information on obtaining other UF/IFAS Extension publications, contact your county's UF/IFAS Extension office. U.S. Department of Agriculture, UF/IFAS Extension Service, University of Florida, IFAS, Florida A \& M University Cooperative Extension Program, and Boards of County Commissioners Cooperating. Nick T. Place, dean for UF/IFAS Extension. 
Distribution: Brazil pusley is found in the southern United States and Hawaii, Jamaica, Brazil, eastern Africa, Sri Lanka, and Java (Lewis and Oliver 1974).

Florida pusley is native to Florida, while Brazil and largeflower pusley are native to South America (Lewis and Oliver 1974).

Largeflower pusley is found in Florida (introduced), Argentina, Bolivia, Brazil, Paraguay, and Uruguay (Lewis and Oliver 1974).

Growth Habit: All species grow prostrate and decumbent (lying low along the soil surface), with varying degrees of branching.

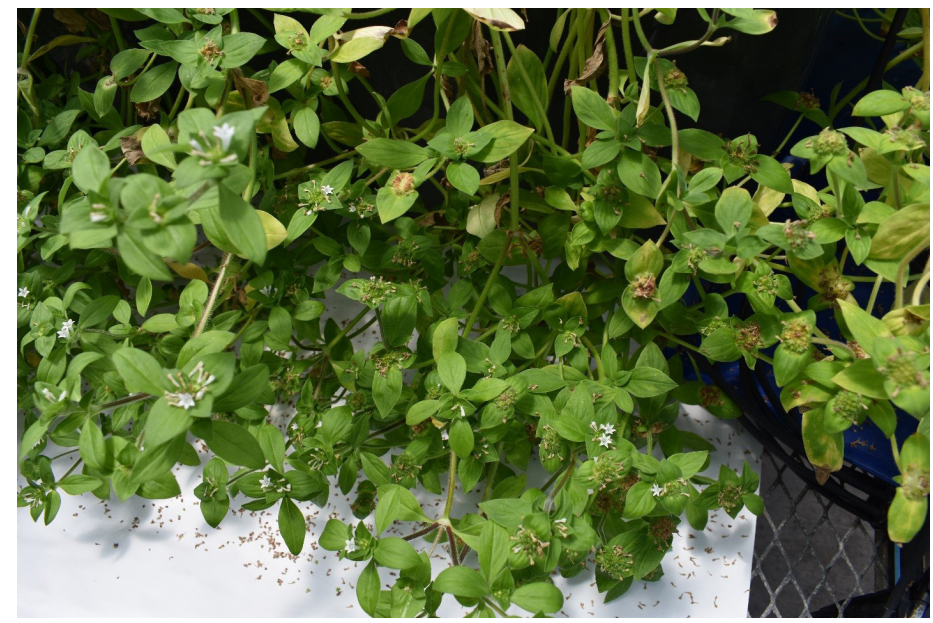

Figure 1. Brazil pusley growth habit.

Credits: Shaun M. Sharpe, UF/IFAS

Seedlings: Hypocotyls (first stem from seed) are green and hairless but may have a slight maroon coloration; cotyledons (first leaves from seed) are smooth with thick blades (Bryson and DeFelice 2009).

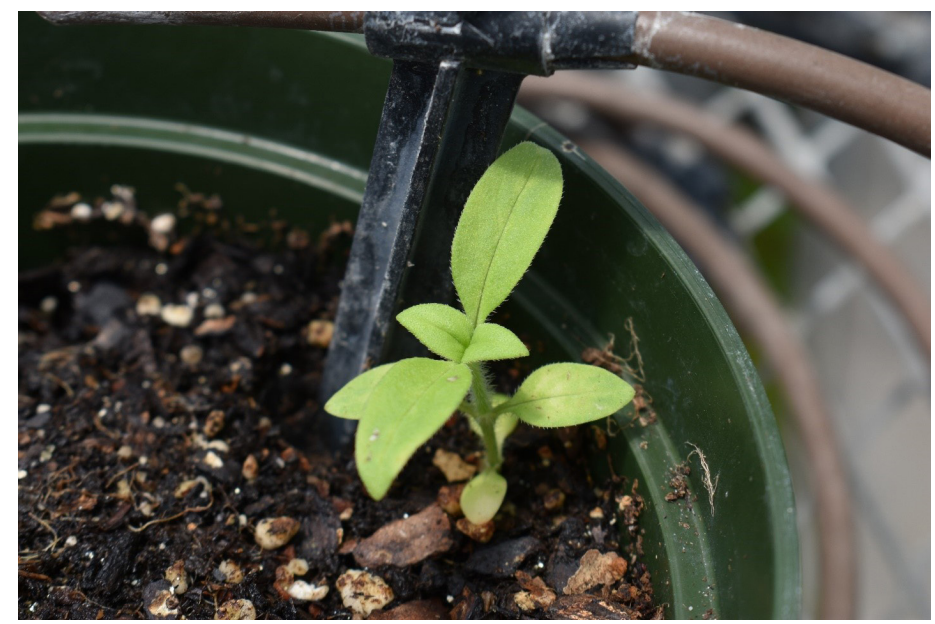

Figure 2. Brazil pusley seedling. Credits: Shaun M. Sharpe, UF/IFAS
Shoots: Round to oval. Hispid (having stiff hairs). Florida pusley has ovate to elliptic-lanceolate leaves (egg-shaped to teardrop-lance-shaped). Brazil pusley has elliptic to ovate leaves (teardrop to egg-shaped) with the leaf tip triangular to rounded (apex acute to obtuse). Largeflower pusley has linear-lanceolate (very lance shaped) and sessile leaves (no leaf stalk) (Lewis and Oliver 1974). Leaf morphology may vary and largeflower pusley may have a similar leaf morphology to Florida pusley when growing in Florida; therefore, morphology is not a good identifier (Lewis and Oliver 1974).

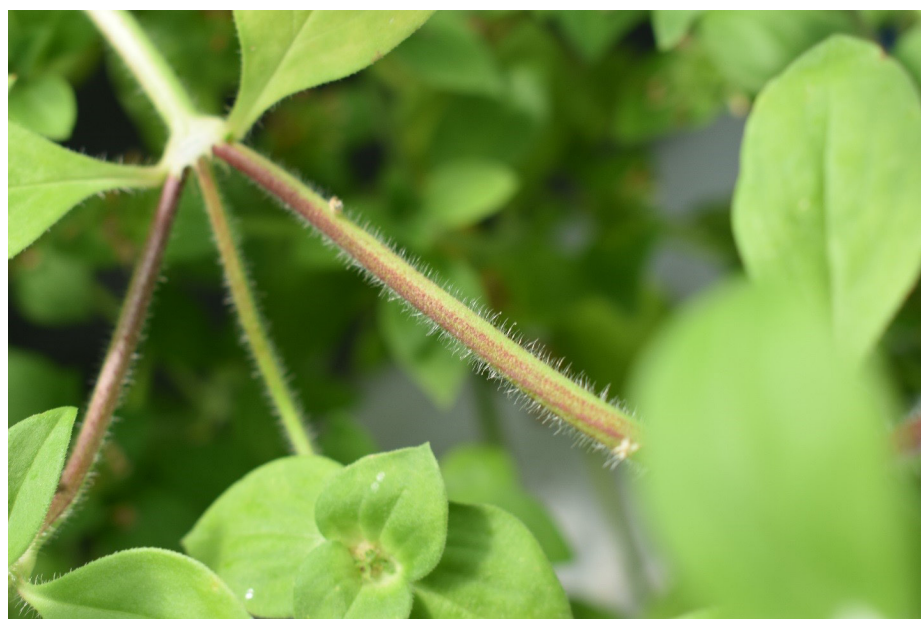

Figure 3. Brazil pusley stem demonstrating the stiff hairs present on the stem.

Credits: Shaun M. Sharpe, UF/IFAS

Roots: Taproot with fibrous roots attached.

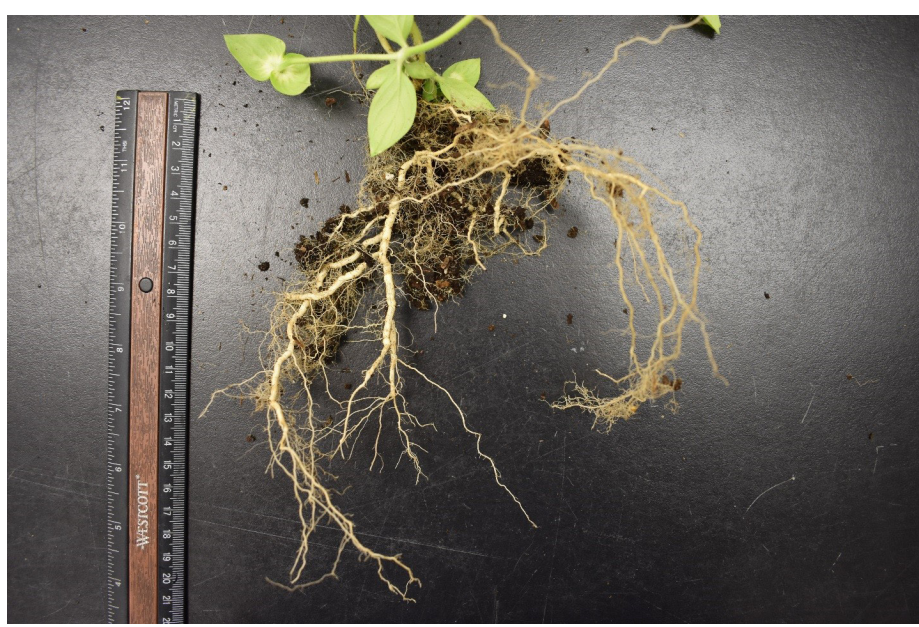

Figure 4. Brazil pusley root system, demonstrating the taproot. Credits: Shaun M. Sharpe, UF/IFAS

Inflorescence: Capitulum (flowering head structure) containing many flowers. Floral parts are in groups of six. Both Florida pusley and Brazil pusley flower year-round, and flowers are typically white and funnelform (shaped like a funnel) (Lewis and Oliver 1974). 


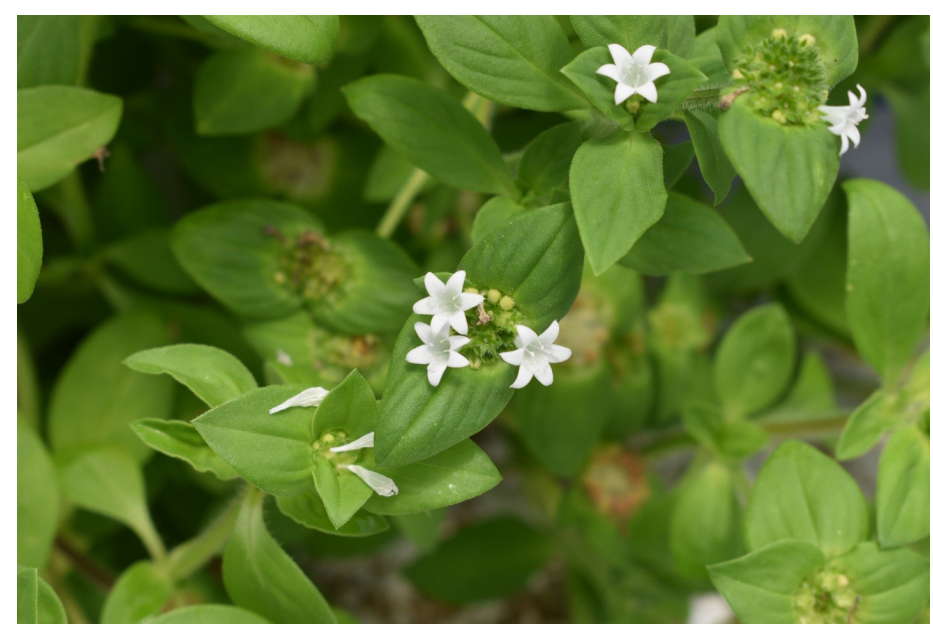

Figure 5. Brazil pusley flowers. Note the whorl (spiral spread) of six petals.

Credits: Shaun M. Sharpe, UF/IFAS

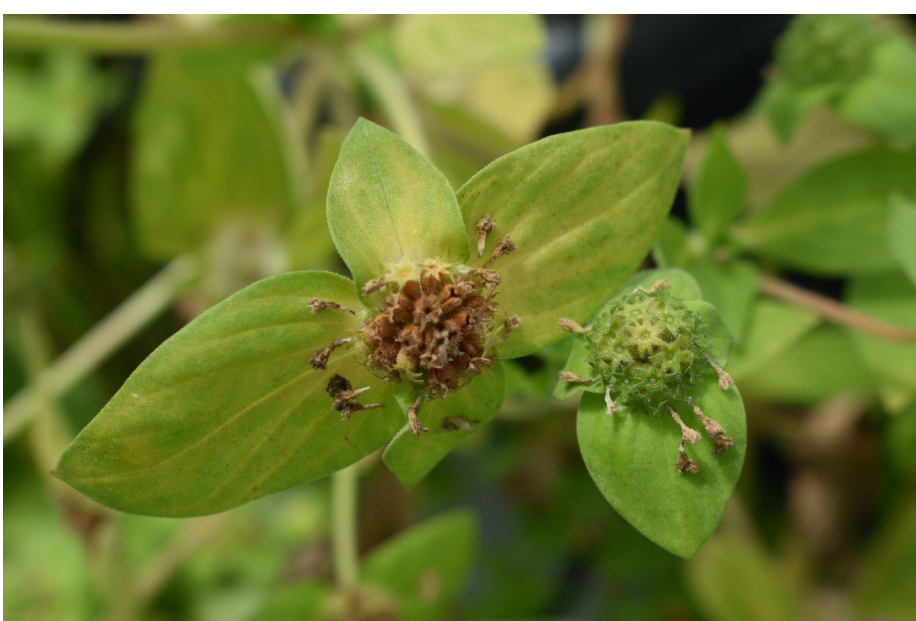

Figure 6. Two Brazil pusley flower heads (capitula) at varying stages of growth. Left: more advanced stage with fruiting structures formed. Right: premature stage, with immature fruit.

Credits: Shaun M. Sharpe, UF/IFAS

Fruit and Seeds: Schizocarp (a dried fruit), divided into three sections (mericarps) (Lewis and Oliver 1974). Mericarps generally fall from the fruiting structure once mature. The best method of discrimination between Brazil, Florida, and largeflower pusley is the mericarp structure (Lewis and Oliver 1974). For example, Florida pusley and largeflower pusley have wart-like outgrowths, Brazilian pusley has hairlike outgrowths, and South American Mexican clover is smooth. Florida pusley seeds have a minimal after-ripening period and may germinate immediately after formation (Biswas et al. 1975).

Similar Species: South American Mexican clover-a perennial with floral parts and mericarps in groups of four (Lewis and Oliver 1974).

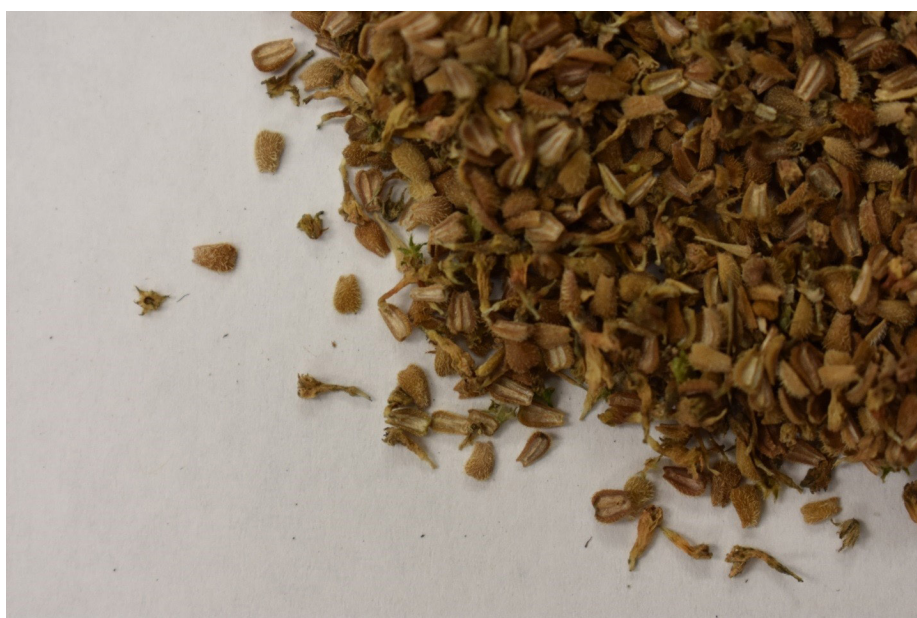

Figure 7. Brazil pusley seed structures (mericarps). Note the presence of some senescent flowers.

Credits: Shaun M. Sharpe, UF/IFAS

\section{Plant Biology}

Florida pusley seed primarily emerges from the soil surface and only tolerates burial of $0.5 \mathrm{~cm}$ (Biswas et al. 1975). The temperature range for Florida pusley germination is between $20^{\circ} \mathrm{C}$ and $35^{\circ} \mathrm{C}\left(68^{\circ} \mathrm{F}\right.$ and $\left.95^{\circ} \mathrm{F}\right)$, with $97 \%$ germination at $30^{\circ} \mathrm{C}\left(86^{\circ} \mathrm{F}\right)$ (Biswas et al. 1975). Germination and emergence can occur year-round in Florida, but these species respond more favorably to warmer temperatures for larger flushes of vegetation.

\section{Management Physical and Cultural Control}

Tillage: Given that moist storage of Florida pusley seed at $5^{\circ} \mathrm{C}\left(41^{\circ} \mathrm{F}\right)$ for 20 weeks reduced germination by $80 \%$ (Biswas et al. 1975), decomposition by burial through tillage may be a viable strategy to control escapes during fallow or prior to bed formation. This strategy may complement delays in planting dates if emergence occurs within the early season.

Hand Weeding: A viable option, especially considering the generally shallow taproot. Given that this species is capable of flowering and producing seed year-round, it is advisable to remove plants that have flowered from the field to prevent seed formation and seed return to the seedbank.

Plastic Mulch: Pusley is unable to penetrate plastic mulch, so its use restricts emergence to planting holes and row middles. A healthy crop is a strong competitor because pusley's prostrate growth habit make it a poor competitor for light. Punching narrow holes in the plastic mulch will restrict space for emergence. Seeds require at least 2 hours of sunlight, so germination under plastic mulch should be minimal (Biswas et al. 1975). It is currently unknown how 
long seed persists in the soil seedbank, but moist storage experiments suggest that the duration of survival is limited (Biswas et al. 1975).

Chemical Control: While the impact of fumigants on Florida pusley seed is unknown, scarification with acid for 14 minutes did reduce germination from $95 \%$ to $42 \%$. Therefore, it is possible that fumigants play a role in controlling the Florida pusley seedbank, but further study is required.

Several herbicides are either labeled to provide control of Florida pusley or have been observed to control Florida pusley. Unfortunately, little to no herbicide efficacy data are available for Brazil and largeflower pusley. Herbicides are grouped based on pre-emergence or post-emergence control of Florida pusley. Pre-emergence implies the herbicides are applied prior to the emergence of the weed. Post-emergence implies the weed has emerged and the herbicide is applied during a susceptible growth stage (generally 3- to 5-leaf stage). Use patterns and restrictions on placement may vary, and the label should be consulted prior to any herbicide applications. Labels change often, so the current label should be consulted every time the product is applied. For more complete herbicide listings, please consult the UF/IFAS Vegetable Production Handbook.

\section{Pre-Emergence}

Cucurbits: On the bed-top when not using plastic mulch, ethalfluralin + clomazone (Strategy) (Group 3+13) is registered to control Florida pusley in cucumbers, melons, pumpkins, squash, and watermelon. There are no other suitable herbicides for use under plastic mulch for cucurbits.

In the row middles, pendimethalin is available for use in cantaloupe, muskmelon, watermelon, and citron melon. Flumioxazin (Chateau) (Group 14) provides excellent control of Florida pusley (label is through Third Party Registrations, Inc.). Alternative herbicides include terbacil (Sinbar) (Group 5) in watermelon and pendimethalin (Prowl) (Group 3) in cantaloupe, muskmelon, watermelon, and citron melon. $S$-metolachlor (Dual Magnum) (Group 15 ) is registered for pumpkin production.

Peppers: On the bed-top, under the plastic mulch, oxyfluorfen (Goal) (Group 14) and napropamide (Devrinol 2-XT) (Group 15) are registered for Florida pusley control. $S$-metolachlor (Dual Magnum) (Group 15) is labeled for use under the plastic mulch (TPR, Inc. label).
Within row middles, flumioxazin (labelled through TPR, Inc.), lactofen (Cobra) (Group 14) (TFR, Inc. label), pendimethalin, and $S$-metolachlor (TPR, Inc. label) provide effective control.

Strawberry: On the bed-top, options include flumioxazin, napropamide, sulfentrazone (Spartan) (Group 14), and oxyfluorfen for Florida pusley control.

In row middles, flumioxazin can be applied post-transplant but prior to fruit set. Alternatively, pendimethalin and napropamide are both registered to control Florida pusley.

Tomato: On the bed-top (under the plastic mulch), metribuzin (Sencor) (Group 5) will provide good control of Florida pusley. Alternative registered products for Florida pusley control in the bed are napropamide, oxyfluorfen, $S$-metolachlor, and sulfentrazone.

In row middles, flumioxazin (labelled through Third Party Registrations, Inc.) provides excellent control. Alternative choices include lactofen (TFR. Inc. label), pendimethalin, and $S$-metolachlor.

\section{Post-Emergence}

Single applications of glyphosate at $0.68 \mathrm{~kg}$ a.e. ha- ${ }^{-1}(0.6$ lbs. a.e. per acre) provide poor control of both Brazil and Florida pusley (Chandran and Singh 2003, Jha et al. 2008, Johnson III and Mullinix Jr 1998). Alternative herbicides or tank mixes should be used in row middles to achieve adequate control.

Cucurbits: No post-emergence herbicides are registered for use on the bed-top in cucurbit production.

In the row middles, paraquat (Gramoxone) (Group 22) can be used in the row middles for cucumber, muskmelon, cantaloupe, pumpkin, squash, and watermelon, but if paraquat or diquat (Reglone Desiccant) (Group22) are to be used for crop termination, we encourage caution because reliance on a single mode of action (group number) may lead to resistance.

Peppers: Lactofen (Cobra) (Group 14) is registered to provide Florida pusley control in row middles. Alternatively, diquat and paraquat are available.

Strawberry: For use on the bed-top, clopyralid (Stinger) (Group 4) is registered for use over the top of the strawberry crop. 
Within the row middles, paraquat is registered for use, and napropamide can be applied prior to bloom.

Tomato: For use on the bed-top, metribuzin is registered.

For use in the row middles, diquat, paraquat, lactofen, and flumioxazin are registered options for Florida pusley control.

\section{IPM Strategy for Pusley Control}

Prior to bed formation: Monitor fields and use control measures if weeds are growing to prevent them from going to seed. This may include tillage or the use of a burn-down herbicide like paraquat applications. During the fallow period, cover crops may provide competition for pusley species, particularly those with taller canopies. Alternatively, pre-emergence herbicides may be utilized, but consideration to the forthcoming crop should be taken due to planting restrictions.

Bed formation: Utilize plastic mulch to restrict where emergence can occur. Use fumigation to potentially kill seeds. Plastic mulch will limit emergence to planting holes and row middles.

Planting-hole control: When available, two herbicides are recommended for pre-emergence control of pusley on the bed-top. This is to reduce the risk of herbicide resistance by using either tank mixes or sequential applications of different modes of action. If this is not feasible, products should be rotated by mode of action between production cycles.

Post-emergence control at the planting-hole is limited to clopyralid in strawberry and no options are available for cucurbits, tomato, or pepper. If there are escapes, handweeding is the best option. Remember that these species can flower continuously and letting plants get too large risks seed return to the soil.

Row-middle control: For pre-emergence control, use of two herbicides with different modes of action is recommended to reduce the risk of herbicide resistance development. This can be accomplished by either using tank mixes of different herbicides or making sequential application with different modes of action. If using only a single mode of action, check that sequential applications with a postemergence product are of a different mode of action.
Postharvest: Paraquat or diquat can be used to control escapes. Care should be taken if using these Group 22 herbicides for row-middle control.

\section{References}

Biswas, P., Bell, P., Crayton, J., \& Paul, K. 1975. Germination behavior of Florida pusley seeds. I. effects of storage, light, temperature and planting depths on germination. Weed Sci 23:400-403

Bryson, C., \& DeFelice, M. 2009. Weeds of the South. Athens: University of Georgia Press. $468 \mathrm{p}$

Chandran, R.S., \& Singh, M. 2003. Survey and control of Brazil pusley (Richardia brasiliensis) in Florida citrus. Proc Florida State Hortic Soc 116:211-214

Jha, P., Norsworthy, J.K., Bridges, W., \& Riley, M.B. 2008. Influence of glyphosate timing and row width on Palmer amaranth (Amaranthus palmeri) and pusley (Richardia spp.) demographics in glyphosate-resistant soybean. Weed Sci 56:408-415

Johnson, W.C., III, \& Mullinix, B.G., Jr. 1998. Stale seedbed weed control in cucumber. Weed Sci 46:698-702

Lewis, W.H., \& Oliver, R.L. 1974. Revision of Richardia (Rubiaceae). Brittonia 26:271-301

Mallory-Smith, C.A., \& Retzinger, E.J. 2003 Revised classification of herbicides by site of action for weed resistance management strategies. Weed Technol 17:605-619.

Webster, T.M. 2014. Weed survey - southern states 2014. Vegetable, Fruit and Nut Crop Subsection. Page 288 in Proceedings of the Southern Weed Science Society 67th Annual Meeting. Birmingham, AL: Southern Weed Science Society 
Table 1. Herbicides registered $(R)$ for use in listed crops with efficacy on Florida pusley. Please refer to the label for specific application patterns, timings, and rates.

\begin{tabular}{|c|c|c|c|c|c|c|c|c|c|}
\hline $\begin{array}{c}\text { Active ingredient } \\
\text { (example trade name) }\end{array}$ & PRE/POST & $\begin{array}{l}\text { WSSA } \\
\text { Group }\end{array}$ & Eggplant & Peppers & Tomatoes & Cantaloupe & Cucumbers & Squash & Strawberry \\
\hline Diquat & POST & 22 & $\mathrm{R}$ & $\mathrm{R}$ & $\mathrm{R}$ & $\mathrm{R}$ & $\mathrm{R}$ & $\mathrm{R}$ & - \\
\hline Clopyralid (Stinger) & POST & 4 & - & - & - & - & - & - & $\mathrm{R}$ \\
\hline DCPA (Dacthal W75) & PRE & 3 & $\mathrm{R}$ & - & - & - & - & - & - \\
\hline $\begin{array}{l}\text { Ethalfluralin + Clomazone } \\
\text { (Strategy) }\end{array}$ & PRE & $3+13$ & - & - & - & - & $\mathrm{R}$ & $\mathrm{R}$ & - \\
\hline Flumioxazin (Chateau) & PRE/POST & 14 & $\mathrm{R}$ & $\mathrm{R}$ & $\mathrm{R}$ & - & $\mathrm{R}$ & $\mathrm{R}$ & $\mathrm{R}$ \\
\hline Metribuzin (Sencor DF) & PRE/POST & 5 & - & - & $\mathrm{R}$ & - & - & - & - \\
\hline Paraquat (Gramoxone) & POST & 22 & $\mathrm{R}$ & $\mathrm{R}$ & $\mathrm{R}$ & $\mathrm{R}$ & $\mathrm{R}$ & $\mathrm{R}$ & $\mathrm{R}$ \\
\hline Lactofen (Cobra) & PRE/POST & 14 & - & $\mathrm{R}$ & $\mathrm{R}$ & - & - & - & - \\
\hline $\begin{array}{l}\text { Napropamide (Devrinol } \\
2-\mathrm{XT} \text { ) }\end{array}$ & PRE & 15 & $\mathrm{R}$ & $\mathrm{R}$ & $\mathrm{R}$ & - & - & - & $\mathrm{R}$ \\
\hline $\begin{array}{l}\text { S-metolachlor (Dual } \\
\text { Magnum) }\end{array}$ & PRE & 15 & $\mathrm{R}$ & $\mathrm{R}$ & $\mathrm{R}$ & - & - & - & - \\
\hline Oxyfluorfen (Goal 2XL) & PRE/POST & 14 & - & $\mathrm{R}$ & $\mathrm{R}$ & - & - & - & $\mathrm{R}$ \\
\hline Pendimethalin (Prowl H2O) & PRE & 3 & $\mathrm{R}$ & $\mathrm{R}$ & $\mathrm{R}$ & $\mathrm{R}$ & - & - & $\mathrm{R}$ \\
\hline Sulfentrazone (Spartan) & PRE & 14 & - & - & $\mathrm{R}$ & - & - & - & $\mathrm{R}$ \\
\hline
\end{tabular}

